\title{
Application of Pervious Concrete: Reuse of Rainwater and Flood Control
}

Daniel Petroche Sánchez ${ }^{l}$, Carol Pacheco Vidal, Arq. ${ }^{l}$, Carlos R. Rodríguez, Ph.D. ${ }^{l}$, Angel D. Ramírez, Ph.D. ${ }^{l}$, Daniel Salas Márquez ${ }^{l}$, Andrea Boero Vera, M.Sc. ${ }^{1}$, Ana Meléndres Palma, Ing. ${ }^{.}$and Jorge Duque-Rivera, M.Sc. ${ }^{.}$

${ }^{I}$ Escuela Superior Politécnica del Litoral,ESPOL, Ecuador,dpetroch@espol.edu.ec, cfpachec@espol.edu.ec, crodrigu@espol.edu.ec,aramire@espol.edu.ec,dasalas@espol.edu.ec,aboero@espol.edu.ec,amelendr@espol.edu.ec, jduque@espol.edu.ec

\begin{abstract}
The present study proposes the implementation of a new system of rainwater disposal, called Sustainable Roads, responding to two issues present in the city of Guayaquil: The effects of the floods as well as the urban rehabilitation of settlements, through the harvesting and reuse of rainwater. The system used as residential roads includes a layer of treat (surface layer/cover) consisting of a kind of concrete so that it has the necessary resistance for residential traffic, but permeable enough so the rainwater can go through the filtering layers made of zeolite and gravel reaching the necessary removal of total suspended solids for its posterior usage. The filtered water conduction occurs through a PVC pipe perforated that guides it to the distribution system, supplying water for discharges from toilets, outdoor cleaning and maintenance of green areas. As a method of abstraction, to verify the correct functioning of this type of roads, a model has been built retrieving flow uptake and solids removal data. The purpose of the implementation of the Sustainable Roads in new projects and in the rehabilitation of irregular settlements areas, is to have a system for the disposal of rain water that works both as an effective flood control, and as the means of its acquisition for the preservation of drinking water while conserving hydric resources.
\end{abstract}

Digital Object Identifier (DOI):

http://dx.doi.org/10.18687/LACCEI2016.1.1.083

ISBN: 978-0-9822896-9-3

ISSN: 2414-6390

$14^{\text {th }}$ LACCEI International Multi-Conference for Engineering, Education, and Technology: "Engineering Innovations for Global Sustainability", 20-22 July 2016, San José, Costa Rica. 


\section{Application of Pervious Concrete: Reuse of Rainwater and Flood Control}

Daniel Petroche Sánchez ${ }^{1}$, Carol Pacheco Vidal, Arq. ${ }^{1}$, Carlos R. Rodríguez, Ph.D. ${ }^{1}$, Angel D. Ramírez, Ph.D. ${ }^{1}$, Daniel Salas Márquez ${ }^{1}$, Andrea Boero Vera, M.Sc. ${ }^{1}$, Ana Meléndres Palma, Ing. ${ }^{1}$ and Jorge Duque-Rivera, M.Sc. ${ }^{1}$

${ }^{1}$ Escuela Superior Politécnica del Litoral, ESPOL, Ecuador, dpetroch@espol.edu.ec, cfpachec@espol.edu.ec, crodrigu@espol.edu.ec, aramire@espol.edu.ec, dasalas@espol.edu.ec, aboero@espol.edu.ec, amelendr@espol.edu.ec, jduque@espol.edu.ec

\begin{abstract}
The present study proposes the implementation of a new system of rainwater disposal, called Sustainable Roads, responding to two issues present in the city of Guayaquil: The effects of the floods as well as the urban rehabilitation of settlements, through the harvesting and reuse of rainwater.

The system used as residential roads includes a layer of treat (surface layer/cover) consisting of a kind of concrete so that it has the necessary resistance for residential traffic, but permeable enough so the rainwater can go through the filtering layers made of zeolite and gravel reaching the necessary removal of total suspended solids for its posterior usage.

The filtered water conduction occurs through a PVC pipe perforated that guides it to the distribution system, supplying water for discharges from toilets, outdoor cleaning and maintenance of green areas.

As a method of abstraction, to verify the correct functioning of this type of roads, a model has been built retrieving flow uptake and solids removal data.

The purpose of the implementation of the Sustainable Roads in new projects and in the rehabilitation of irregular settlements areas, is to have a system for the disposal of rain water that works both as an effective flood control, and as the means of its acquisition for the preservation of drinking water while conserving hydric resources.
\end{abstract}

\section{INTRODUCTION}

A. Urban growth

As a consequence of the continuous population growth in the Ecuadorian cities, two urban conceptions have been produced; irregular settlements and the proliferation of inmobiliary projects in the cities surrounding areas.

Focusing on the city of Guayaquil, the plausibility of horizontal growth of the city has led to the development of urbanizations, and irregular settlements, as a response to the need of housing by two different socio-economical classes, but with the same needs of habitability in terms of infrastructure, accessibility and comfort. These two types of settlements require circulation routes that not only grant quick access, but also allow to accommodate the distribution of drinking water facilities and sewage disposal.

One of the perennial social problems for the municipality of Guayaquil is the provision of drinking water and sewage service, as well as the paving of the streets for the settlements that were not designed under the light of a technical and urban optic, considering the topography, height of flood, etc. Increasing the degree of difficulty to answer effectively to the needs of habitability of the population.

\section{B. Flood control}

Digital Object Identifier (DOI): http://dx.doi.org/10.18687/LACCEI2016.1.1.083 ISBN: 978-0-9822896-9-3

ISSN: $2414-6390$

$14^{\text {th }}$ LACCEI International Multi-Conference for Engineering, Education, and Technology: "Engineering Innovations for Global Sustainability", 20-22 July 2016, San José, Costa Rica.
One of the consequences of the technical failure or urban planning becomes evident every winter with the floods of citadels. Since the rain water or sewage system (if it is a combined system: sewage and rain water) fails to be sufficient to the intensity of rain, it collapses, flooding streets and even housing sectors causing the proliferation of diseases plus economic losses. [1]

Controlling floods in a city as Guayaquil with a high annual rainfall, with a traditional system for rainwater disposal (gutters, drains and pipes), is even more difficult if a proper control has not existed since its conception, yet that's the case in the previously described irregular settlements.

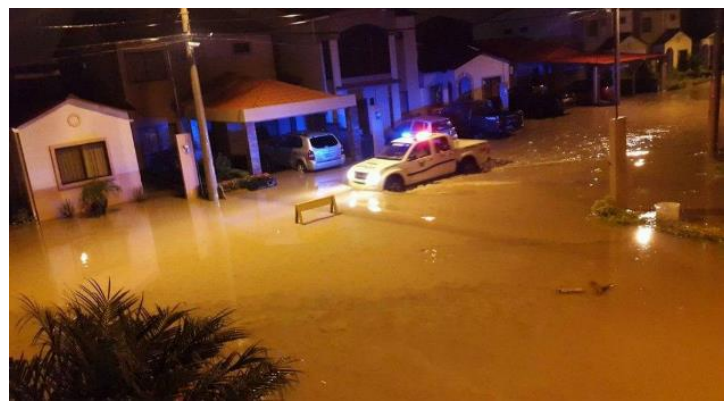

Fig. 1 Floods in areas of adjacent real estate projects to Guayaquil.[1]

C. Sustainability

The preservation of water resources has become a repeated element in any project with a sustainable grade. A practical way conceived has been the uptake of rainwater to be treated and subsequently used as drinking water, irrigation or recreation. This treatment changes according to the water quality parameters required for its consumption. Rainwater reuse would not only lead to the decrease of water consumption coming from the supply system, but it would also reduce the flow entering the waste water treatment plants, helping to save costs and preserving water sources such as rivers.

\section{SCOPE}

For the feasibility of this project's implementation, three important aspects are to be considered; the need of flood control works, the hydrology of the site and availability of materials.

The need for flood control works covers both the demand for housing due to population and commercial growth of the area, as the locations of the study area in flood-prone areas.

The hydrology of the site defines both the intensity and the periods of rain annually, with which the dates for the reuse of water rain and the volumes to be captured can be defined. 
When combining the need for flood control works and the hydrology of the site, they become key factors on the feasibility of the project's implementation, since in the absence of them, the floods can be prevented with conventional civil works.

But as it is well known, in Ecuador, especially in provinces of the coastal region like Guayas, Los Ríos, Manabí, that are linked to the great basin of the Guayas River, there are many areas prone to flooding, as it has been perceived over the years [2]. Being almost imperative to seek solutions to reduce and prevent damage.

Finally, the availability of the materials needed for the construction of the pavement as well as the filter bedding, are necessary because the conceivability of the costs of work is affected.

"Sustainable Roads: reuse of rainwater and Flood Control" can be run in any area where it's implementation is needed, it may have a regional scope, without neglecting the variables described in this section.

This project in a specific manner, performs a local diagnosis of Guayaquil and surrounding areas, analyzing the standard residential area of the city.

\section{LITERATURE REVIEW}

\section{A. Design of rigid pavements}

Rigid pavements are structural road elements consisting of a slab of concrete which has a considerable flexing resistance allowing them to perform as if they were beams, they suffer little deterioration, its maintenance expenditure is low, but they have a higher cost than flexible pavements.

In the 1960s, the AASHTO design method was developed in the United States by the American Association of officers of state highways and transportation (AASHTO), based on a test scale for 2 years in the State of Illinois, for the purpose of making formulas and correlations that represent the proportionality between the deterioration and the demand of different sections of flooring by users.

The improved version is the AASHTO 93, published in the year of 1993, which presents a concept of serviceability on the design of pavement as a measure of capacity to generate a layer of tread smooth and comfortable for the user. [3]

\section{B. Pervious concrete}

In accordance with the ACI 522R-10, the term "pervious concrete" typically describes a material's texture with a nearzero slump, its dosage consists of cement, coarse aggregates, little or no fine aggregate, additives and water. The combination of these ingredients will produce a resistant material with enough cement paste to cover the particles aggregate thickness, with connected pores, which range in size from 2 to $8 \mathrm{~mm}$, allowing water to pass through them easily. The empty content can vary from 15 to $35 \%$, with a compressive strength from 3.0 to $18 \mathrm{MPa}$. The drainage of the pervious concrete floor rate will vary with the size of the aggregates and the density of the mixture. Furthermore, the pervious concrete floor reduces the impact of urban development through the reduction or elimination of rates of runoff of rainwater, replenishing the natural aquifers. [4]

\section{Zeolite and its application in water treatment}

Mechanisms of removal of particles (filtration), depend on a complex combination of physical and chemical mechanisms in water treatment, adsorption is the most important role, since as the water runs through the filter bedding, suspended particles (TSS: total suspended solids) come in contact and are adsorbed on the surface of the grains of filtering material. [5]

Zeolites are Nonmetal mineral compounds, which belong to the Group of the tectocilicates and chemically are hydrated aluminosilicates. Currently, approximately 60 natural zeolite species have been recognized and possess characteristics of selective adsorption, being that the reason why they are called "molecular sieves". In Ecuador, research on zeolites has been happening from the early 1990s, since the year 2000, important universities in the region in cooperation with well renown universities from Belgium and Spain, have been studying the presence of zeolites in the province of Guayas[6], specifically in the Cayo formation, estimating $1423375 \mathrm{~m} 3$ of exploitable zeolite. [7]

\section{METHODOLOGY}

\section{A. Design of rigid pavements by the AASHTO 93 method}

The design of rigid pavements by the AASHTO 93 method involves the analysis of different variables such as traffic, characteristics of the soil, drainage, climate, level of desired serviceability, load transfer capability, and the degree of reliability of the results according to the importance of the road.

The use of all factors predicts a reliable behavior of the structure of the floor avoiding the collapse in its service life.

The fundamental equation of the AASHTO 93 flooring rigid is as follows:

$$
\begin{array}{r}
\log \left(W_{18}\right)=Z_{R} S_{0}+7.35 \log (D+1)-0.06+\frac{\log \left(\frac{\Delta P S I}{4.5-1.5}\right)}{\frac{1.624 \times 10^{7}}{(D+1)^{8.46}}} \\
+\left(4.22-0.32 P_{t}\right) \log \left(\frac{S_{c}^{\prime} C_{c}\left(D^{0.75}-1.132\right)}{215.63 J\left(D^{0.75}-\frac{18.42}{\left(\frac{E_{C}}{k}\right)^{0.25}}\right)}\right)
\end{array}
$$

The design considerations are described below:

$\mathrm{W}_{18}$ : is the number of loads of 18 kips planned for a period of life.

$Z_{R}$ : value area under the curve of standardized distribution, for reliability $\mathrm{R}$.

$\mathrm{S}_{0}$ : variable standard deviation.

D: thickness of pavement [in].

$\Delta$ PSI: loss of serviceability.

Pt: Final serviceability.

$S^{\prime}$ c: modulus of rupture concrete [psi].

$14^{\text {th }}$ LACCEI International Multi-Conference for Engineering, Education, and Technology: "Engineering Innovations for 
J: charge transfer coefficient.

Cd: drainage coefficient.

Ec: module elasticity concrete [psi].

$\mathrm{k}$ : sub-surface reaction module [psi/in].

\section{B. Pervious concrete dosing}

The process of permeable concrete mixture proportions development is often repeated with efforts of trial and error. Generally, a balance must be found between voids content, resistance, workability and paste content. ACI provides a method for essay mixtures that provides a pervious concrete intended to be used on floors and other applications where the drainage, filtration and high porosity are needed [4].

The most relevant considerations for the dosage of pervious concrete are described below: no.4).

Aggregates. Size 7 (1/2 "to 4), 8 (3/8" to 8), 67 (3/4"to

Cement. Adjusted to the norm NTE INEN 490 [12] or NTE INEN 2380 [8].

Water: Is used for drinking water or other water that complies with the regulations. [9]

Water/cement ratio: Important consideration to obtain the desired resistance and void structure into the pervious concrete. Between 0.26 and 0.45 water/cement ratio ranges will produce the best coating for aggregates and stability of paste.

Empty content: To ensure that the water will pass through the void, the void contents must be greater than or equal to $15 \%$.

Amount of added thickness: The dry density of compacted coarse aggregate is used [10], to dose Pervious concrete.

Paste volume, water and cement content: The dosage of Pervious concrete seeks to establish a minimum volume of paste needed, maintaining the necessary void structure, providing strength and workability.

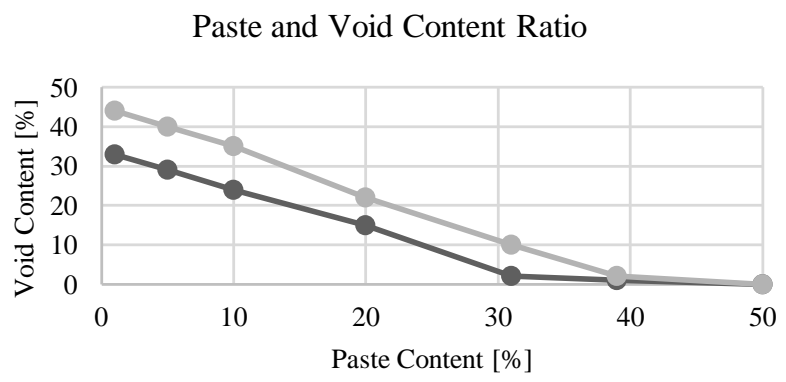

- High Compaction $\quad-$ Light Compaction

Fig. 2 Rate of cement paste over assumed percentage of voids in a volume

After the volume of paste has been determined and selected, the mixture water/cement ratio, the amount of cement and water can be determined by the following relationship of absolute volumes:

$$
\mathrm{Vp}=\mathrm{Vc}+\mathrm{Vw}
$$

Once the concrete has been dispensed and produced, it must be tested to the requirements of quality control [11], but the necessary trials for the design of pavement are resistance to compression and bending of concrete. [12][13]

\section{Removal of TSS with zeolite filter}

The total suspended solids are a portion of solids that are retained on a filter free from ashes of fiberglass with a porosity of approximately $0.45 \mu \mathrm{m}$. Previously weight, a wet filter is placed in a filtering appliance where suction is applied, then the filter containing the residue is dried in an oven then the sample is cooled. The difference in weights are the total suspended solids which are expressed in milligrams of suspended solid per liter of filtered water. [14]

\section{Estimation of flow rain}

For the estimation of the maximum flow of rain, we will use an empirical method, the rational method, which consists in the application of the following equation:

Q: maximum flow rate $\left(\mathrm{m}^{3} / \mathrm{s}\right)$

C: runoff coefficient

I: intensity of rain $(\mathrm{m} / \mathrm{s})$

A: contribution area $\left(\mathrm{m}^{2}\right)$

The runoff coefficient is of projects normal nature and is estimated continuously.

It is important to define that for the application of the method, we need to have an area smaller than $1500 \mathrm{Ha}$ and a concentration time not higher than 6 hours of rain.

E. Abstraction a pervious concrete pavement section.

For removals of TSS and the infiltration coefficient calculation, we use an abstraction of our sustainable pathway of $0.25 \mathrm{~m} 2$, which was built with estimated measures of our structure of pavement with the following configuration:
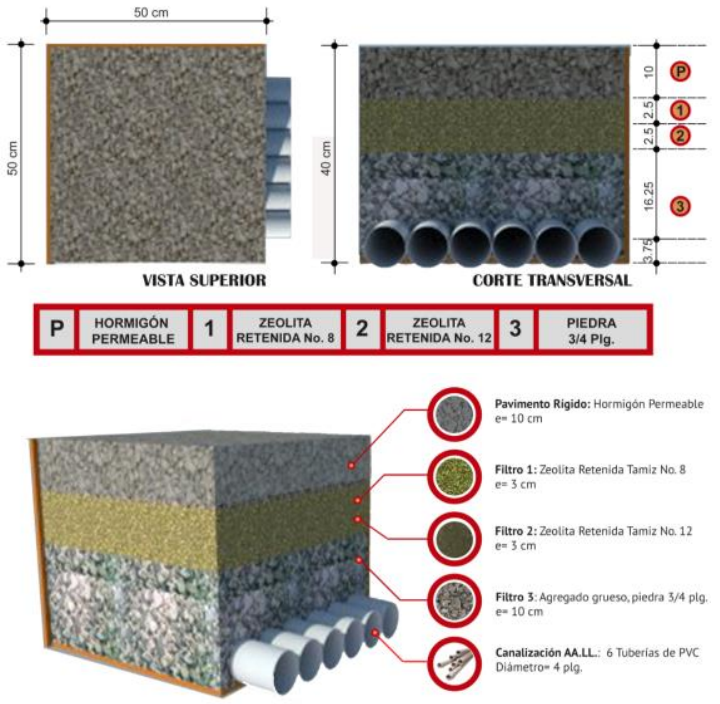

Fig. 3 Section of sustainable pavement with a description of its components

$14^{\text {th }}$ LACCEI International Multi-Conference for Engineering, Education, and Technology: "Engineering Innovations for Global Sustainability”, 20-22 July 2016, San José, Costa Rica. 
The pavement was built in a way that mimics the true construction process, placing 6 pipes of 4 inches in diameter that simulate an average collection of rain water pipe, a layer of stone was placed with the function of the drainage layer, 2 layers of zeolite with nominal maximum size of $2.36 \mathrm{~mm}$ and 1 $\mathrm{mm}$ respectively were over imposed.

The design of Pervious concrete previously dispensed, was designed, which was submitted to the compressive strength tests [12] and Flex [13], parameters necessary for the design of rigid AASHTO 93 flooring. Subsequently the pavement was submitted to real conditions of flow rates for the calculation of removals of SST and infiltration coefficient where a volume was poured and the outgoing volume of the pipes was measured, obtaining the following results:

TABLE I

CALCULATION OF COEFFICIENT OF INFILTRATION

\begin{tabular}{|c|c|c|}
\hline \multicolumn{2}{|c|}{ Volume (litres) } & \\
\hline Income & Output & $\mathrm{C}$ \\
\hline 20 & 16.4 & 0.82 \\
\hline 20 & 16.2 & 0.81 \\
\hline 20 & 16.6 & 0.83 \\
\hline 20 & 16.4 & 0.82 \\
\hline & $\mathrm{C}=$ & 0.82 \\
\hline
\end{tabular}

TABLE II

REMOVALS OF TSS WITH ZEOLITE FILTER

\begin{tabular}{|c|c|c|}
\hline \multicolumn{2}{|c|}{ TSS (mg/L) } & \multicolumn{1}{|c|}{ \% Removal } \\
\hline SST0 & TSSF & $65 \%$ \\
\hline 637.42 & 220.24 & $64 \%$ \\
\hline 670.36 & 241.64 & $64 \%$ \\
\hline 694.32 & 252.78 & $62 \%$ \\
\hline 720.96 & 273.12 & $65 \%$ \\
\hline 790.44 & 280.46 & $64 \%$ \\
\hline
\end{tabular}

TABLE III

SIMPLE COMPRESSION OF

PERVIOUS CONCRETE CYLINDERS TESTED AT 28 DAYS

\begin{tabular}{|c|c|c|c|c|}
\hline $\begin{array}{c}\mathrm{d} \\
\mathrm{mm}\end{array}$ & $\begin{array}{c}\mathrm{h} \\
\mathrm{mm} \\
\end{array}$ & $\begin{array}{c}\text { Density } \\
\mathrm{kg} / \mathrm{m} 3\end{array}$ & $\begin{array}{c}\mathrm{P} \\
\mathrm{KN} \\
\end{array}$ & $\begin{array}{c}f^{\prime} \mathrm{c} \\
\mathrm{kg} / \mathrm{cm} 2 \\
\end{array}$ \\
\hline 101 & 201 & 2142.97 & 157.9 & 200.96 \\
\hline 100.9 & 200 & 2168.58 & 156.5 & 199.57 \\
\hline 100.1 & 200 & 2176.06 & 157.1 & 203.55 \\
\hline \multicolumn{2}{|c|}{ Density $=$} & 2162.54 & $f^{\prime} c=$ & 201.36 \\
\hline
\end{tabular}

TABLE IV

BENDING STRENGHT IN PERVIOUS CONCRETE BEAMS TESTED AT 28 DAYS

\begin{tabular}{|c|c|c|c|c|}
\hline $\begin{array}{c}\mathrm{b} \\
\mathrm{mm}\end{array}$ & $\begin{array}{c}\mathrm{h} \\
\mathrm{mm}\end{array}$ & $\begin{array}{c}\mathrm{L} \\
\mathrm{mm}\end{array}$ & $\begin{array}{c}\mathrm{P} \\
\mathrm{KN}\end{array}$ & $\begin{array}{c}\mathrm{Mr} \\
\mathrm{kg} / \mathrm{cm} 2\end{array}$ \\
\hline 151 & 150 & 450 & 15.4 & 20.78 \\
\hline 151 & 150 & 450 & 15.1 & 20.38 \\
\hline \multicolumn{5}{r}{} \\
\cline { 4 - 5 } & $\mathrm{MR}=$ & 20.58 \\
\hline
\end{tabular}

\section{PROPOSED SOLUTIONS}

Sustainable Roads: Reuse of rainwater and Flood Control consists of the calculation, design and construction of a rigid paving with pervious concrete on a filter of natural zeolite, allowing the proper evacuation of rainwater and its subsequent reuse, avoiding flooding and creating a culture of sustainable design, optimizing the use and safekeeping of available water resources.

For the calculation a formal settlement type was considered, located in the surrounding areas of the city of Guayaquil, composed of 466 lots for residential use, approximately 2330 inhabitants and the following land use:

TABLE V

DESCRIPTION OF LAND USE PROJECT OF STUDY

\begin{tabular}{|c|c|c|}
\hline Use & $\begin{array}{c}\text { Surface } \\
(\mathrm{m} 2)\end{array}$ & Percentage \% \\
\hline 466 lots & 64826.32 & $59.91 \%$ \\
\hline Club & 1920.13 & $1.77 \%$ \\
\hline Green area & 10994.75 & $10.16 \%$ \\
\hline Pathways & 27088.63 & $25.03 \%$ \\
\hline Treatment plant & 3377.17 & $3.12 \%$ \\
\hline Total & 108207 & $100.00 \%$ \\
\hline
\end{tabular}

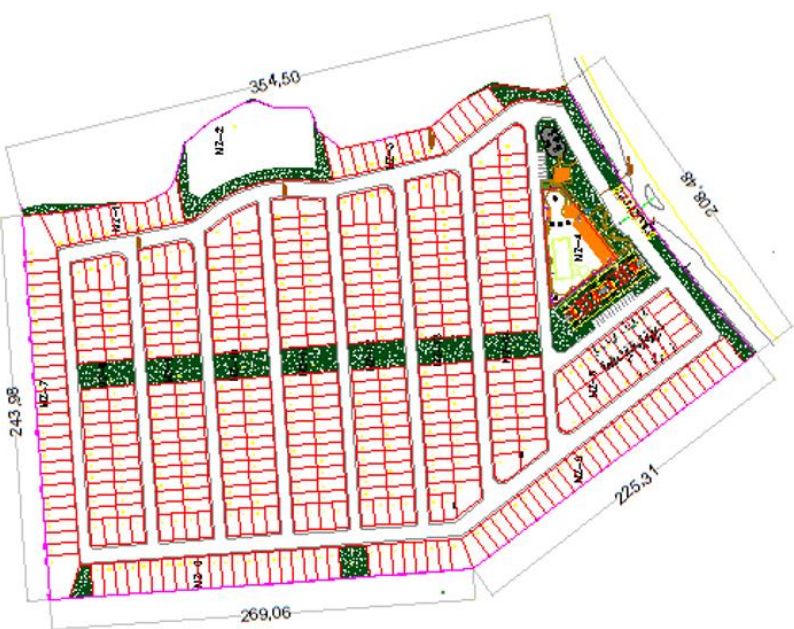

Fig. 4 General allotment of the project of study

$14^{\text {th }}$ LACCEI International Multi-Conference for Engineering, Education, and Technology: "Engineering Innovations for Global Sustainability”, 20-22 July 2016, San José, Costa Rica. 


\section{A. Calculation of rigid pavement and concrete dosage:}

Based on the information previously gathered, the AASHTO 93 general equation for the design of rigid pavement was applied and the ACI method for the dosage of pervious concrete.

TABLE VI

ENTRY OF CALCULATION VARIABLES AASHTO93

\begin{tabular}{|c|c|c|c|}
\hline \multicolumn{5}{|c|}{ AASHTO 93 design } \\
\hline W18 & 5321660 & MR & $2018992.5 \mathrm{psi}$ \\
\hline ZR & -0.253 & CD & 1.2 \\
\hline S0 & 0.34 & EC & $292.7 \mathrm{psi}$ \\
\hline PT & 2 & K & 25 \\
\hline$\Delta$ PSI & 2.5 & D & 10.6 inch \\
\hline J & 2.8 & D & $23.32 \mathrm{~cm}$ \\
\hline
\end{tabular}

TABLE VII

DOSAGE RESULT OF PERVIOUS CONCRETE

\begin{tabular}{|c|cc|c|cc|}
\hline \multicolumn{7}{|c|}{ Pervious concrete dosage for $1 \mathrm{~m}^{3}$} \\
\hline PUC & 1425 & $\mathrm{~kg} / \mathrm{m} 3$ & A. thickness & 1449.23 & $\mathrm{~kg}$ \\
\hline Po & 1.7 & $\%$ & Cement HE & 409.84 & $\mathrm{~kg}$ \\
\hline $\mathrm{a} / \mathrm{c}$ & 0.31 & & Water & 127.05 & $\mathrm{~kg}$ \\
\hline VP & 0.25 & $3 \mathrm{~m}$ & Empty $\%$ Real & 17.79 & $\%$ \\
\hline Empty \% & 10 & $\%$ & \multicolumn{1}{|c}{} \\
\cline { 1 - 3 } & & &
\end{tabular}

The result of the thickness of the pavement is $23.32 \mathrm{~cm}$, which for safety was round up to $25 \mathrm{~cm}$.

\section{B. Design capture, re-use of rainwater and Flood Control}

For the design of the collection system, rainwater reuse and flood control, a citadel type model was used.

\section{Permeability coefficient $(C)$}

According to abstraction explained in the methodology section, we calculated a coefficient of permeability of 0.82

\section{Rainfall intensity (I)}

By applying the equations developed for the city of Guayaquil INAMHI (1999):

$$
I_{T R}=288.42\left(t^{-0.7779}\right) I d_{T R}
$$

According to a runoff which occurrence has a return period of 10 years, with a daily intensity $\left(I d_{T R}\right) 6.5 \mathrm{~mm} / \mathrm{h}$ and for a duration of 6 hours (t) rain time, an intensity of precipitation $\left(I d_{T R}\right)$ is $19.25 \mathrm{~mm} / \mathrm{h}$ is obtained.

\section{E. Area of contribution (A)}

The input area is of $27088.63 \mathrm{~m} 2$, which corresponds to the area of routes ( $25 \%$ of the area of implementation)

\section{F. Period of uptake of rainwater}

The rainy season extends from November to June, however the increased rainfall occur during January to May, considering this as the period of uptake for the system, being the maximum rainfall for 24 hours during the rainy period regular to the city of Guayaquil from 70 to $150 \mathrm{~mm}$ and an average of $25 \mathrm{~mm}$ according to the INOCAR. [15]

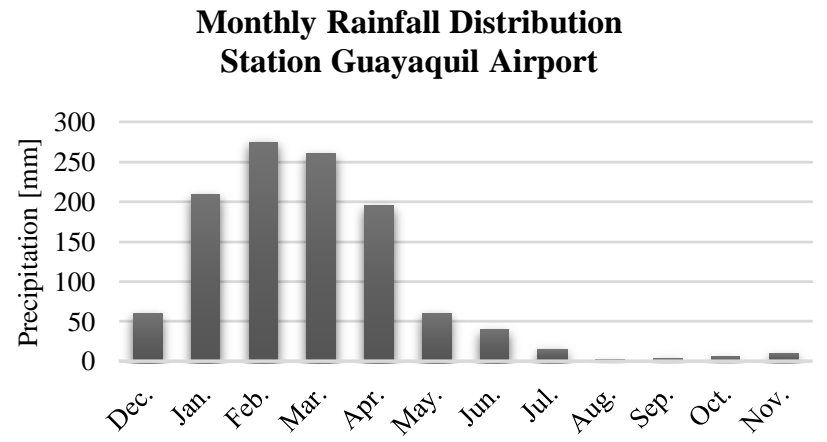

Fig. 5 Monthly distribution of rainfall in the city of Guayaquil. [15]

G. Flow rate and volume of recruitment

The rational method formula was used for the determination of the flow of rainwater to capture $(\mathrm{Q}=\mathrm{CIA})$. Represents a flow of $0.119 \mathrm{~m} 3 / \mathrm{s}$ and considering a duration of 6 hours average rain, estimated an available volume of 42.76 $\mathrm{m} 3$ for a day during the period of system acquisition.

\section{H. Flow and volume required}

The reuse of rainwater is directed to activities that require the range of removal of solids from the total solids within the retrieved through the simulation carried out for the prototype described in the methods section.

The activities are grouped into three functions: recharge toilet tanks, outdoor cleaning and maintenance of green areas.

The demands of cleaning and maintenance are based on ranges of usage and number of toilet tanks according to that consideration that for each for each flush 4 liters of water with are used and a repetition of 3 times per day, per person.

TABLE VIII

CALCULATION OF REQUIRED WATER FLOW BY DAILY CONSUMPTION AVARGES IN GUAYAQUIL

\begin{tabular}{|c|c|c|c|c|c|}
\hline Use & Flowrate & Lt/week/ & \multicolumn{2}{|c|}{ Units } & \multirow{2}{*}{$\begin{array}{l}\text { Lt/week } \\
195720.00 \\
\end{array}$} \\
\hline WC & $12 \mathrm{Lt} / \mathrm{d} /$ per & 84 & 2330 & per & \\
\hline Gardens & $2-6 \mathrm{Lt} / \mathrm{d} / \mathrm{per}$ & 2 & 11926.75 & $\mathrm{~m} 2$ & 23853.50 \\
\hline $\begin{array}{l}\text { Outdoor } \\
\text { cleaning }\end{array}$ & 2-6 Lt/d/per & 2 & 8155 & $\mathrm{~m} 2$ & 16310.00 \\
\hline & & & \multicolumn{2}{|c|}{ Lt/week } & 235883.50 \\
\hline & & & \multicolumn{2}{|l|}{$\mathrm{Lt} / \mathrm{d}$} & 33697.64 \\
\hline & & & \multicolumn{2}{|c|}{$\mathrm{m} 3 / \mathrm{d}$} & 33.70 \\
\hline
\end{tabular}

$14^{\text {th }}$ LACCEI International Multi-Conference for Engineering, Education, and Technology: "Engineering Innovations for Global Sustainability”, 20-22 July 2016, San José, Costa Rica. 


\section{Operation of the system}

The uptake of $42,76 \mathrm{~m} 3 /$ day of water receipted by the pervious concrete paving will be properly filtered by layers of stone materials shown in the diagram, the rainwater solids removed and captured by the perforated pipes, feeding a separate distribution system reaching to every unit of housing toilet and an exterior faucet for the cleaning and irrigation. As considered only the $78.8 \%$ of the catchment will be used, the remaining will be led to two cisterns that combined will store a volume of $40 \mathrm{~m} 3$, enough to meet the demand for a day. This cistern will be connected to the system of drinking water supply of the Citadel with the purpose that the distribution system works without the need for a dual supply system.
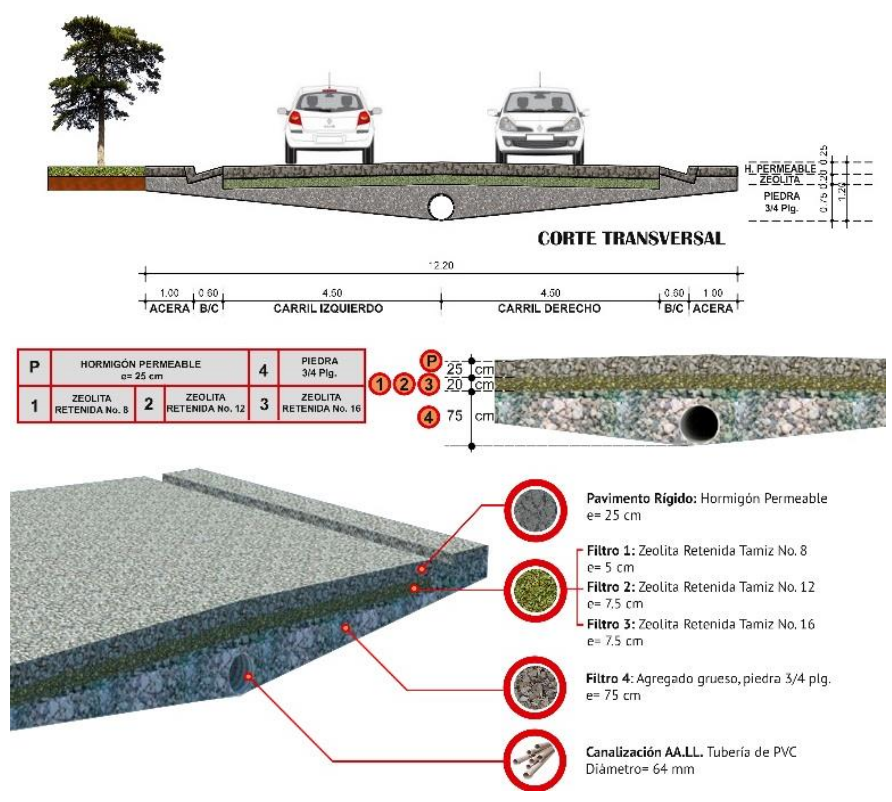

Fig. 6 Description of the sustainable pavement system: Reuse of rain water and flood control

\section{FEASIBILITY}

\section{A. Environmental}

A regular endowment for residential use of $200 \mathrm{~L} / \mathrm{Hab} \mathrm{x}$ day is being considered, through the reuse of rainwater captured by the paving of vehicular traffic routes, with 14.46 liters reused per person, achieving a saving of $7.23 \%$ of drinking water consumption.

During the rainy season, specifically during the months of January to May, a flow rate of $10.85 \mathrm{~m} 3$ per house would not enter the water treatment facilities.

\section{B. Social}

According to the INEC, from the urban sectors, only $71.1 \%$ of dwellings have a paved or cobbled road of access. Meaning that $28.9 \%$ of the access to dwellings are not properly paved. This percentage corresponds to the unplanned settlements, sectors which this project is aiming.
At the same time, in Guayaquil, $21.8 \%$ of the population is considered poor by unsatisfied basic needs that cover the lack of a sewerage and a proper rainwater evacuation system.

\section{Economical}

The average drinking water consumption per month for a family of 5 members is of $30 \mathrm{~m} 3$, which corresponds to $\$ 16.50$ monthly payment. When a system for reusing rainwater through pervious concrete with the characteristics previously described is implemented, a citadel residence would save $\$ 1.19$ monthly and $\$ 14.28$ annually.

\section{CONCLUSIONS}

Through the application of Sustainable Roads as an option for the design of citadels or even as an alternative paving for one that has already been designed, solutions for the rehabilitation of roads are obtained together with the reduction of drinking water consumption, flood control and preservation of water resources.

1. If the population to be served in Guayaquil due to the lack of sewage and rain water evacuation is of 150000 homes approximately, by using 78.8 percent of the rainwater uptake from roads, i.e. a volume of 72.31 liters/House per day. During the months of January to Maya flow of $10846 \mathrm{~m} 3 /$ day would not enter the treatment facilities, same flow that would also not inundate the streets of citadels or informal settlements during the rainy season.

2. Through trials done to the pervious concrete pavement implemented, it has become clear that it can address to the same requirements of conventional concrete in terms of resistance and serviceability, reaching a simple compressive strength by the 28th day of 201.36 $\mathrm{kg} / \mathrm{cm} 2$ and a modulus of rupture of $20.59 \mathrm{~kg} / \mathrm{cm} 2$.

3. The use of zeolite in its natural state as filter material is viable, both because of its accessibility as an autochthonous material and due to its solids removal characteristic, retaining pollutants like hydrocarbons from cars or any other type of external agent.

4. By the abstraction built it has been shown that $82 \%$ of the input flow was collected and led by pipes, which when presented with the flow demand for reuse in a real model, exceeds the percentage needed to meet this demand. Furthermore, the removal obtained in the prototype was of $64 \%$, enough percentage for the rainwater to be used in the proposed activities.

\section{CONCLUSIONS}

Sustainable Roads: Reuse of Rain Water and Flood Control was conceived aiming to find a solution from the engineering perspective to one of the problems with highest incidence in Ecuador, seeking not only to mitigate the complications of the floods, but additionally focusing on getting the most benefits from water resources. 
The designed Citadel, by possessing a dual system of collected water and drinking water can (even if a large precipitation like El Niño where the volumes of water are high) use the system purely to evacuate the rainwater preventing floods.

The present project yearns to set the guidelines for future urban designs to possess a real component of sustainability, reduce the use of soil in impermeable roads and parking lots, which are the main cause of flooding, through pervious channels, looking for design policies that ensure the normal development of the population and their sustainability over time.

\section{REFERENCES}

[1] "Inundación sorprendió a residentes de Villa Club," El Universo, 06May-2015. [Online]. Available: http://www.eluniverso.com/noticias/2015/05/06/nota/4844361/inunda cion-sorprendio-residentes-villa-club. [Accessed: 13-Sep-2015].

[2] "Tres millones y medio de ecuatorianos afectados por inundaciones FEB. 22, 2008 - El País - Historicos - EL UNIVERSO.” [Online]. Available:

http://www.eluniverso.com/2008/02/22/0001/12/BD6EC5A295444A2 3A39CE29A46702BC0.html. [Accessed: 13-Sep-2015].

[3] A. A. of S. H. and T. Officials, AASHTO Guide for Design of Pavement Structures, 1993. AASHTO, 1993.

[4] A. ACI, “522R-10. 2010," Rep. Pervious Concr. ACI Comm., vol. 522, p. 38.

[5] J. A. Romero Rojas, "Tratamiento de aguas residuales, teoría y principios de diseño," Bogotá CO Esc. Colomb. Ing., 2004.

[6] D. Garcés, "Caracterización mineralógica del depósito de zeolitas naturales en el río guaraguau (isidro ayora, provincia del Guayas) y su aplicación en la remoción de amonio en aguas residuales," May 2013.

[7] A. J. Coloma Nazareno and E. Peña Carpio, "Gestión del movimiento de tierras y aprovechamiento de las zeolitas naturales existentes en el parque tecnologico del campus-ESPOL," Jan. 2002.

[8] Instituto Ecuatoriano de Normalización (INEN), "NTE INEN 2380: 2005 Cementos Hidráulicos," Requisitos Desempeño.

[9] Instituto Ecuatoriano de Normalización (INEN), NTE INEN 2617: Hormigón de Cemento Hidráulico. Agua para Mezcla. Requisitos. .

[10] Instituto Ecuatoriano de Normalización (INEN), NTE INEN 0858: Áridos. Determinación de la masa unitaria (peso volumétrico) y el porcentaje de vacíos. .

[11] Instituto Ecuatoriano de Normalización (INEN), NTE INEN 1855-1: Hormigones. Hormigón premezclado. Requisitos. .

[12] Instituto Ecuatoriano de Normalización (INEN), NTE INEN 1573: Hormigón de cemento hidráulico. Determinación de la resistencia a la compresión de especímenes cilíndricos de hormigón de cemento hidráulico. .

[13] Instituto Ecuatoriano de Normalización (INEN), NTE INEN 2554: Hormigón de cemento hidráulico. Determinación de la resistencia a la flexión del hormigón. (Utilizando una viga simple con carga en los tercios).

[14] "Methods for the Chemical Analysis of Water and Waster, U.S. Environmental Protection Agency, EPA 600/4-79-020, p. 160.2, (1979)."

[15] "Instituto Oceanográfico de la Armada - Precipitación por estación." [Online]. Available: http://www.inocar.mil.ec/web/index.php/precipitacion-por-estacion. [Accessed: 14-Sep-2015].

$14^{\text {th }}$ LACCEI International Multi-Conference for Engineering, Education, and Technology: "Engineering Innovations for Global Sustainability", 20-22 July 2016, San José, Costa Rica. 